\title{
A REVIEW OF SOME RECENT WORK ON THE MAMMALIAN REPRODUCTIVE OYCLE
}

\section{By George W. Corner}

Workers in the physiology of reproduction, usually undertaking investigations to serve their practical needs as gynecologists or animal breeders, have found themselves under the necessity of understanding the reproductive cycles of some of the common domestic mammals, and have thus been forced to study natural history in a field but little cultivated by the faunal naturalists. In the end, however, gain may be had in both directions, for it can hardly be doubted that important evolutionary trends underlie the present extraordinary diversity of the reproductive phenomena of mammals. It will not be necessary to point out here extended illustrations of this diversity; we may briefly recall that among the ungulates alone we have such phenomena as the annual rutting of deer, in some species accompanied by violent oestrous manifestations in both sexes; in ewes an annual season of several repeated "heats;" in domesticated sows and cows a perennial cycle of about twenty-one days interval. In the laboratory rodents there appear to be perennial cycles of diverse lengths, with outward manifestations so slight that they may evade even the practised watcher; while in the catarrhine apes and man we have a perennial cycle averaging four weeks, with what might be called a dispersed oestrus, and with the additional phenomenon of menstruation. Internally the same apparent diversity reigns; mammals differ as much in their uteri as in their brains, and the comparative ovarian histologist might almost duplicate some feats of the paleontologist who names a species from a single tooth or vertebra, for it requires but little skill to distinguish all the common domestic mammals by glancing at sections of their ovaries. These histological differences concern not only mere details of architecture and of size, but also the duration of growth of the corpus luteum, the rate and type of atresia of the Graafian follicles, and the amount of interstitial tissue.

Attempts to untangle the problem have led, during recent decades, to the development of two general ideas about which current work is centering. It seems probable, first, that in all mammals the ripening of ova is a regularly periodic function accompanied by characteristic changes primarily in the ovaries and secondarily in the whole reproductive tract; and second, that these changes are continued after ovulation 
in such a way that the uterus is prepared to receive and nourish the embryos which may result from the ovulation if mating occurs. It is likely that all the phenomena of the female reproductive cycle can in the end be related to these two ideas.

With regard to the first point an important step was gained by Stockard and Papanicolaou (1917) when by extending certain old and almost unnoticed observations they showed that the oestrus of the guinea-pig, outwardly so inconspicuous, is actually marked by a series of characteristic changes in the vaginal wall, so that microscopic examination of a smear of the vaginal fluid enables the observer to predict the occurrence of ovulation with accuracy. At intervals of about fifteen days there is first a desquamation of epithelial cells and then the passage of white blood cells in great numbers through the vaginal wall; if the animal is killed on the day of these changes its ovaries are found to contain ripe follicles with mature ova, and the uterine epithelium is in a characteristic state interpreted by Stockard and Papanicolaou as indicating active degeneration.

Long and Evans $(1920,1921)$ whose preliminary notes are about to be extended in a comprehensive monograph, have attained such accuracy with similar studies on the albino rat that they can predict the time of ovulation within one hour, and in their hands the method is already serving as a tool for the investigation of many problems of the oestrous cycle. In the white rat ovulation is very frequent (every four to six days), the interval being actually less than the time required for the passage and implantation of the fertilized ova. It will be seen that this frequency would inevitably lead to superfoetation, were it not for a special mechanism discovered by Long and Evans, namely that the act of copulation itself postpones the next ovulation for a sufficient length of time to protect the mother from a second crop of ova, until the pregnancy itself can work the usual further postponement. The mechanism by which this end is attained seems to be a reflex from the genital canal, for the mere insertion of a glass rod into the cervix uteri is as effective as a normal copulation.

Allen (1921) has worked out a similar cycle in the albino mouse; and we may now look forward to the application of such studies to some of the supposedly special cases among rodents, such as the rabbit, in which it is said that ovulation cannot be completed without copulation. No applications of this method to mammals of other orders have as yet been reported, although there is good reason to expect interesting results in this direction. However there have been several contri- 
butions sharpening our knowledge of the relation between ovulation and oestrus in animals showing marked outward signs of heat, as for instance those of Longley (1912) on the cat, Lewis (1911) and Corner and Amsbaugh (1917) on the sow, and Küpfer (1920) on the cow. In all these animals oestrus is promptly followed by the development of corpora lutea in the ruptured Graafian follicles.

The second general idea outlined above has slowly grown out of the suggestion of Prenant and Born that the corpus luteum is a gland of internal secretion, serving to produce changes in the uterus and ovary. Later workers, inclüding Fraenkel, L. Loeb, Ancel and Bouin, Hill and O'Donoghue, and others, have developed the hypothesis by assuming that the changes effected by the corpus luteum are aimed at facilitating the implantation of the embryos. The best experimental attack on the problem was made in 1907 by Leo Loeb, who found that (in the guinea-pig) when newly-formed corpora lutea are present in the ovaries, and then only, the uterine mucosa is in a specially responsive state, so that the presence of the ova, or even of an artificial foreign body, leads to the production of a decidual or placenta-like change of the uterus. In its simplest form this beautiful experiment, now several times confirmed by others, requires only that one select an animal about one week after an unfertilized ovulation, and traumatize the uterine mucosa with a needle. Four or five days later the stimulated areas are marked by the presence of swellings histologically resembling decidual tissue. Preliminary removal of the ovaries (or, according to Loeb, of the corpora lutea alone) prevents the formation of the deciduomata.

The present writer has attempted, by way of testing the foregoing considerations, to study the whole ovarian and uterine cycle in one species, and to make the supposed utility of the uterine changes for implantation of the embryos something more than a matter of hypothesis, by actually correlating the state of the uterus at every stage with the progress of the ova and embryos. For this purpose the domestic sow was chosen, because it appears to be the only mammal whose earliest embryology and mode of implantation are as yet sufficiently known and accessible to re-study which at the same time exhibits uncomplicated and outspoken oestrous phenomena.

It has been found, in brief, that the external manifestations of oestrus, which recur at intervals of about twenty-one days, are associated with a regular ovarian cycle. A day or two before the onset of oestrus a group of follicles is prepared for ovulation; they rupture 
during the oestrous period, and are succeeded by corpora lutea, which reach their full development in one week, and remain in active state until the fifteenth day after ovulation, when they suddenly degenerate to make way for a new group of follicles. If the ova are not fertilized they pass into the uterus and degenerate there about the seventh or eighth day; but if fertilized they become attached to the uterine mucosa between the tenth and fifteenth days, at the very time when the corpora lutea are at their height. (In this case, of course, the corpora lutea do not degenerate, but persist throughout pregnancy.) There is also a parallel series of changes in the uterus. At oestrus the uterine mucosa is in a state like that described in the rodents by Stockard and Papaincolaou and by Long and Evans; but during the following week it undergoes marked growth changes, and during the second week (the time of implantation) still further histological modifications take place which seem clearly adapted to aid first in transporting and then in attaching the embryos. These alterations go on, however, whether or not the ova are fertilized; but if no embryos are formed, then when the corpora lutea degenerate the uterine mucosa also reverts to its original condition, and by the simultaneous occurrence of epithelial degeneration and proliferation is brought back to the oestrous stage.

Long and Evans (1921) find that in the albino rat there are characteristic changes of the vaginal mucosa during the first weeks of pregnancy. Under the conception which we have been outlining, similar changes should occur after an unfertilized ovulation, but it appears that their full development is aborted by the briefness of the cycle in this species. However, as Long and Evans have discovered, if the return of oestrus be postponed by the insertion of a glass rod into the cervix uteri, as described above, then the vagina shows changes in every way similar to those of pregnancy.

It will be apparent from the foregoing review that this branch of investigation has now reached a stage of exploration and of comparison, and that there is a pressing necessity for careful study of the reproductive habits of all accessible mammals. From the medical standpoint an especial interest attaches to the mechanism of reproduction in the primates, and it is here that the greatest service can be rendered by those who deal with wild animals at large and in captivity, by gathering together enough information to give a basis for experimental work. We have seen that this work must be founded upon specific knowledge of life-processes; at present we have little more than hearsay and travellers' tales about the reproductive cycle of the monkeys and apes. 
For instance, though it is at last definitely known that the old-world monkeys undergo menstrual phenomena very similar to those of the human species, yet with regard to the new-world forms all one can learn after somewhat persistent querying is that no one has seen a menstruating platyrrhine monkey; whether these American monkeys have an annual breeding season, or bear young at all seasons of the year, does not appear in books of natural history. These questions will serve to show the importance of a field of inquiry in natural history, as yet almost unexplored, in which are to be gained results of immediate practical utility. And finally, as we hinted at the beginning, it is not beyond hope that when common laws are understood through all the diversity of form and function, light may be thrown upon some of the wider questions of mammalian evolution.

\section{PAPERS CITED}

Allen, E. 1921. The oestrous cycle in the mouse. Proc. Amer. Assoc. Anat., 37th Session, Anat. Rec., xxi, 43.

Corner, G. W., and Amsbaugh, A. E. 1917. Proc. Amer. Assoc. Anat., 33rd Session, 1916. Anat. Rec., ii, 345.

Corner, G. W. 1921. Cyclic changes in the ovaries and uterus of the sow, and their relation to the mechanism of implantation. Publications of the Carnegie Institution of Washington, No. 276 (Contributions to Embryology, no. 64).

KÜPFER, M. 1920. Beiträge zur Morphologie der weiblichen Geschlechtsorgane bei den Säugetieren. Denkschr. d. Schweiz. Naturf. Gesellsch., lvi.

Lewis, L. L. 1911. The vitality of reproductive cells. Bull. No. 96, Agric. Exp. Station of Oklahoma.

Loeb, L. 1907. Ueber die experimentelle Erzeugung von Knoten von Deciduagewebe in dem Uterus des Meerschweinschens. Centralbl. f. allg. Path. xviii, 563.

Long, J. A., And Evans, H. M. 1920. The oestrous cycle of the rat, etc. Proc. Amer. Assoc. Anat. 36th Session, Anatomical Record, xxi, 56.

1921. Further studies on the physiology of reproduction. Ibidem. vol. 21,56 .

LONGLEY, W. H. 1911. Maturation of the egg and ovulation in the domestic cat. Amer. Jour. Anat., xii, 139.

Stockard, C. R., and Papanicolaod, G. N. 1917. The existence of a typical oestrous cycle in the guinea-pig with a study of its histological and physiological changes. Amer. Jour. Anat., xxii, 225.

Anatomical Laboratory, Johns Hopkins University, Baltimore 


\section{$2 \mathrm{BHL}$ Biodiversity Heritage Library}

Corner, George W. 1921. "A Review of Some Recent Work on the Mammalian Reproductive Cycle." Journal of mammalogy 2, 227-231. https://doi.org/10.2307/1373556.

View This Item Online: https://www.biodiversitylibrary.org/item/220033

DOI: https://doi.org/10.2307/1373556

Permalink: https://www.biodiversitylibrary.org/partpdf/90607.

\section{Holding Institution}

Smithsonian Libraries

\section{Sponsored by}

Biodiversity Heritage Library

\section{Copyright \& Reuse}

Copyright Status: Not in copyright. The BHL knows of no copyright restrictions on this item.

This document was created from content at the Biodiversity Heritage Library, the world's largest open access digital library for biodiversity literature and archives. Visit BHL at https://www.biodiversitylibrary.org. 